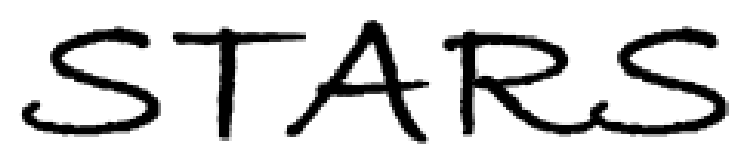

University of Central Florida

STARS

Faculty Scholarship and Creative Works

$9-1-2012$

\title{
Assessing Tourism Development from Sen's Capability Approach
}

Robertico R. Croes

University of Central Florida, robertico.croes@ucf.edu

Part of the Hospitality Administration and Management Commons, and the Tourism and Travel Commons

Find similar works at: https://stars.library.ucf.edu/ucfscholar

University of Central Florida Libraries http://library.ucf.edu

This Paper is brought to you for free and open access by STARS. It has been accepted for inclusion in Faculty Scholarship and Creative Works by an authorized administrator of STARS. For more information, please contact STARS@ucf.edu.

\section{Original Citation}

Croes, R. (2012). Assessing tourism development from Sen's capability approach. Journal of Travel Research. 51(5), 542-554.

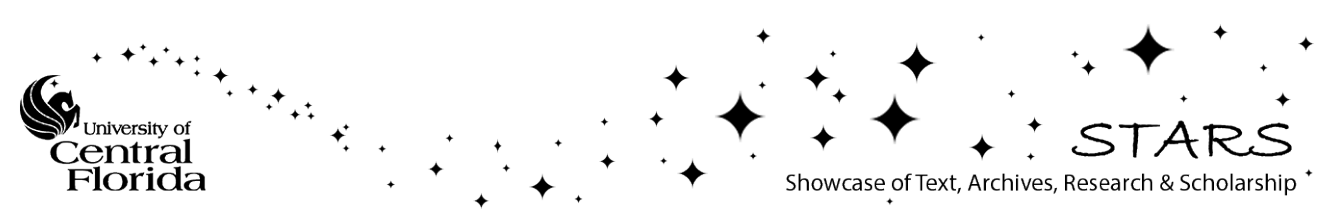


Croes, R. (2012). Assessing tourism development from Sen's capability approach. Journal of Travel Research, 51(5), 542-554.

\section{ASSESSING TOURISM DEVELOPMENT FROM SEN'S CAPABILITY APPROACH Abstract}

The purpose of this study is to assess tourism development in the context of Sen's capability approach. The study developed a model to investigate the relationship between tourism development and human development while focusing on two countries, Nicaragua and Costa Rica. The study applied a cointegration technique based on the Granger representation theorem. Overall, tourism development and human development reveals a tenuous relationship in both cases, reflecting some threshold effect. The importance of tourism growth is merited in the distribution of its benefits and the extent that tourism receipts are allocated to support human development (public health, education, safety, etc.). Rising incomes will not necessarily translate into human development performance, thereby rendering support to Sen's contention that wellbeing should not be measured by its instrumental antecedents (such as income) alone. Private incomes through tourism expansion seem to matter most at lower levels of human development. Keywords: tourism development, human development, Sen's capability approach, cointegration. 


\section{Introduction}

The purpose of this study is to assess tourism development in the context of Sen's capability approach. It investigates how tourism development and human development are related. In investigating the nature of this relationship, the study aims at discerning the intertemporal interaction between tourism development and human development. In other words, it attempts to answer the question whether human development is an input or an output of tourism development. For the purpose of this study, human development is defined as the command of basic capabilities, such as a long and healthy life, and the enlarging of people's choices to have a meaningful and creative life (Sen, 1999). Human development is a multidimensional concept and focuses on people, not on market and income.

Approaches regarding development have shifted in recent times from rising incomes to the distribution of incomes to a focus on the reduction of poverty (Anand and Ravallion 1993; Ranis, Stewart and Ramirez 2000). The premise of all these approaches pertains to the central role of income growth in the development equation. The meaning of development took a different twist with the introduction of the Human Development Reports produced by the United Nations Development Program (UNDP). These reports are underpinned by the conceptual approach espoused by Amartya Sen's work (1982, 1985, 1992, 1997, 1999, 2000). In his view, the essence of economic development is to promote human development, i.e., what people can actually do and be. The tourism literature seems completely lacking in the application of the capabilities approach of Sen. Only two studies refer only superficially to Sen's theoretical foundations (Hashimoto 2002; Cracolici and Nijkamp 2009).

While the debate has broadened the definition and goals of development, the relationship between growth, tourism development and human development (HD) has not received much attention in the tourism literature. Some studies in the tourism literature conflate 
development/wellbeing as opulence (income and/or commodity command) (Balaguer and Cantavella-Jorda 2002; Durbarry 2004; Dritsakis 2004; Narayan 2004; Croes and Vanegas 2008). Other studies have considered the correlation of availability of goods and subjective well-being through surveys (Neal, Sirgy and Uysal 2004; Perdue, Long and Kang 1999; Kim 2002; Gilbert and Abdullah 2002; Andereck, Valentine, Vogt and Knopf 2007; Liburd and Derkzen 2009; Moscardo 2009). Little attention has been paid to defining development as capabilities or the increase of choices available to the person as suggested by Sen (1999).

Understanding the link between tourism development and human development could provide policy makers with relevant social policy. Tourism is considered as a relevant development tool in the literature. Uncovering the strength of the nexus between tourism development and human development could increase our understanding in establishing the right balance between private incomes and public provisioning of social services. The key policy implication is that if expansion of opportunities influences human development independent from tourism development, then expansion of opportunities requires a government intervention focusing not only on tourism but also on provisioning of social services. On the other hand, if tourism is growth enhancing and growth enhancing is improving capabilities, then government intervention should mainly focus on tourism development. This determination is, however, an empirical question meriting further research regarding whether tourism is to play a role in uncovering real opportunities for enhancing quality of life.

The study addresses the proposition that tourism development expands capabilities. Specifically, it attempts to answer three interrelated questions: (i) is there a relationship between tourism expansion and human development; (ii) if there is a relationship, what is the nature of that relationship; and (iii) what is the direction of the relationship. The study is not concerned 
with the determinants or drivers of the relationships between tourism expansion and human development, but rather to explore the relationship between changes in tourism expansion and changes in human development.

The study measures human development through the UNDP human development index (HDI). The HDI is a composite index and comprises three elements measuring human capabilities: (i) health (ii) education, and (iii) standard of living. Health is captured by life expectancy; education by literacy and school enrollment and standard of living by the GDP per capita. The value for each of these components is transformed into an index using a normalization formula in which the actual value is compared to a stylized range of values across all countries. 


\section{Literature Review}

\section{From Being Well to Well-Being: The Instrumentalist Approach}

For quite some time, the development paradigm was explained as the efficient alignment of preferences and utility. Preferences were centered in the pursuit of gaining the maximum amount of commodities and services; and utility was founded on the realization of these preferences. Individuals were considered homogenous with equal chances to participate in this material pursuit; and the efficient mobilization of resources to achieve this goal was considered the most important assignment of a collectivity of individuals (Solow, 1956). The transformation process from preferences into utility was seen as a kind of a black box, while efficiency was equated with growth, the latter being captured through an income metrics. From this perspective, the ultimate objective of economic life is to procure more income and consumption thereby enabling a better standard of living (well-being) of a population through a trickle-down effect (Aghion and Bolton, 1997).

The development debate focused on the factors and forces affecting the efficient mobilization of resources and in the unraveling of the mystery of the transformation black box in increasing growth. It considered human resources as a significant input or determinant in the creation of growth, in terms of education, health and nutrition, thereby propelling the well-being of a population (Sandler, 2001). And yet, the mystery persists as some countries grow whilst enabling a better standard of living, while others grow without a better standard of living; or, others don't grow at all thereby increasing human misery. In other words, the explanation of this instrumentalist view of human behavior still falls short in explaining the non-linearities in the growth paths of countries. 


\section{The Capabilities Approach: broadening the definition and goals of development}

Sen $(1985,1997)$ addressed the non-linearity mystery by positing that the end game of the economic life is not the command of resources; instead what matters is how people are able to function with the resources at their disposal. Investigating the effects of resources on the human being seemingly enabled Sen to unlock the mystery of the black box. He discovered the multidimensional feature of individuals thereby positing that an income metrics is inadequate to capture the full array of the diversity of human beings. Sen posits that opulence (income and commodities) or utility (happiness) as measures of well-being placed the wrong focus on what should be assessed in terms what constitute development. According to Sen (1999), development and well-being should be more directly linked to their foundational roots and not to their instrumental antecedents.

Sen (1985) argues that individuals vary in their ability to convert resources into wellbeing thereby rendering the possession of resources as a poor indicator of well-being. Human diversity therefore is being affected by personal and the existing social arrangements. The quality of a person combined with the role of the social environment affect human choice and agency and determines the opportunities available for a person (Sen, 1999). The construct of capabilities is therefore the range of opportunities present for an individual to pursue the lifestyle that he/she values and determines the range of achievements (functionings) possible for the individual, such as a good job. Achievements, or what Sen terms 'functionings,' depend on an individual's potential or 'capabilities' to choose among available options.

Capabilities refer to the ability of an individual to function, to seize opportunities, to make choices and to take actions. This ability is contingent upon objective elements, such as quality of education, life expectancy, poverty, employment, discrimination and subjective 
elements such as memory, ethics, common sense, reason, etc. Consequently, the concept of wellbeing shifts from command of resources (inputs) to achievements (outputs). This shift is particularly concerned with the process of widening choices and the influence of people, especially those who are disenfranchised, such as women, minorities and the poor.

Well-being, according to Sen's conceptualization, is a result of the freedom that an individual possesses to achieve conditions in life (to eat, to read, to move, etc.), given his subjective characteristics and endowment of commodities (Sen, 1999). While the notion of functioning and capability seems interconnected, such as health and education, the notion may also determine capabilities (to consume, to move, to work, or to vacation). This suggests that freedom to attain seems more relevant than functionings themselves. The reason seems that capability does not correlate closely to attainment, such as income. One example is life expectancy, a proxy of health. Although life expectancy is the same for Costa Rica as it is for the United States, 78 years, the United States has an income per head four times as high. While this approach considers that a low income, for example, could be an indicator of poverty, the target for income is not an end in itself. Rather, it is a means to achieving functionings.

Development from this perspective means broadening choice and reducing deprivation. Understanding the process of widening choices is relevant in our understanding why marginalized segments in developing countries are removed from the benefits of development. For example, given two persons with similar income, one can walk freely in his neighborhood while the other's freedom to walk is constrained by a crime infested area. For example, this would be the case in Central America where the crime rate is three times higher than the world average. It appears that women (gender), older people (age) and minorities (exclusion) are more 
often victims of crime than other groups (UNDP, 2010). Clearly, these people have a different quality of life.

Therefore, many choices appear to be unrelated to income. For example, countries with similar level of incomes can have very different level of human development (see Table 1). This does not mean however that increased incomes are not relevant in increasing the range of choices and opportunities by a person. Capabilities depend therefore on two intertwining factors: the command over resources and the person's use of the acquired capabilities for work and leisure. The lack of choice, according to Sen $(1992,1999)$, is the result of not only the command of resources but is also the consequence of how these resources are distributed among individuals as well as the degree of propensity of individuals, households and governments to prioritize human development (education, longevity, nutrition, leisure, etc.) in the expenditures. Lack of capacity to make choices or take actions is viewed as underdevelopment rather than the lack of income or the possession of commodities per se. The central concern of the capability approach is therefore providing all human beings the opportunities of a full life rather than insisting on economic growth (Sen, 1985). Persons thus become the ends of the productive process, instead of means of production (Sen, 1999).

Figure 1 provides a conceptual model of the interconnectedness of the components comprising the capability approach. The instrumental relationship between income and low capability is variable between different communities, households and individuals.

\section{INSERT FIGURE 1}




\section{The Capability Approach and the Pro-Poor Debate}

Sen (1999) makes a distinction between "growth mediated" and "support led"

development. The former operates through rapid and broad based economic growth, which facilitates the expansion of basic capabilities through higher employment, improved prosperity and better social services through trickle-down effects. The growth-mediated approach has received support by mainstream economic literature through empirical assessment (Kakwani, 2000; Dollar and Kraay, 2002; Easterly, 2002). The "support led" approach works through proficient welfare programs that support health, education and social security. Fundamentally, the issue refers to the opportunity and role of private incomes to foster development or public capital to provide for the broadening of opportunities and choices (Anand and Ravallion, 1993).

A social arrangement that prevents the widening of choices justifies, according to Sen, prioritizing attention and resources to focus on the reduction of poverty. This seems at the heart of the pro-poor debate and the identification of poverty as one of the main ills to be eradicated by the United Nations. The mainstream literature identifies two distinctive strands regarding the concept of pro-poor: a growth focus on poverty outcomes and a growth focus on inequality outcomes (Ravallion, 2004). The growth focus on poverty outcomes asserts that as long as the poor can share in the benefits of economic growth, economic growth is considered pro-poor. This means that growth is pro-poor if it reduces poverty even if inequality increases (Ravallion and Chen, 2003). This narrow conceptualization of what pro-poor is contradicted by Sen (1997) who argues that the insistence of the development debate on efficiency has blurred the relevance of fairness and equity in the pursuit of a higher quality of life thereby confounding the role of the market in pursuit of social optimality. 
The second strand in the literature addresses the question of who benefits from growth. This strand posits that growth is pro-poor only if the growth rate of the income of the poor is greater than the non-poor (White and Anderson, 2000; Kakwami and Pernia, 2000). In other words, growth benefits the poor if inequality is reduced. This strand within the literature considers inequality as a breaker for poverty reduction. For example, Lopez and Serven (2004) found that growth explains a much smaller proportion of poverty reduction in richer countries than poorer countries. Inequality under this condition functions as filter in between growth and poverty reduction. This broader conceptualization of pro-poor is in line with Sen $(1997,1999)$ who distinguishes the notion of efficiency from equity: an action that might improve everyone's well-being may enhance some people's welfare more than others.

Broadening the definition and goals of development has also meant a revisiting of the proper role of government in supporting the new objective of development. The capability approach views the provisioning of public programs as the main instrument to support human development and to attribute relatively less importance to the role of economic growth (Sen, 1999). This view signifies a shift from the mainstream development literature which views private incomes as a significant lever to reduce poverty (Easterly, 2002). Getting the right balance between public or private provisioning has been a thorny issue in economics.

\section{Measuring Capabilities}

The shift in the development focus has significant implications regarding the questions posed in assessing development and its corresponding metric. The capability approach broadens the informational base to assess well-being according to the ability and possibilities to choose rather than from income. If social and economic arrangements should focus on expanding 
capabilities, rather than income or utilities, which capabilities should they expand or promote? In other words, what constitutes the dimensions of human development?

Sen rejects the existence of a canonical list applicable at all times and in all places. He insists on the heterogeneity and diversity of individuals, cultures and societies which in his view may lead to different values and aspirations (Sen 1985, 1992,1999) thereby indicating that the establishment and evaluation of capabilities are context dependent and this process is dynamic in nature. He seems nevertheless willing to compromise with a basic list of capabilities to undertake pressing social problems, such as extreme poverty. Clark (2005), Robeyns (2005), and Alkire (2007), among others, correctly point out that the identification and ranking of capabilities remain the toughest operationalization issues to be addressed both on foundational and empirical grounds. Capabilities are unobservable variables that can only be observed through indicators as latent variables.

Several strategies have been propounded in dealing with the identification problem. For example, Nussbaum $(2000,2006)$ suggests a list of ten "central human functional capabilities", including being able to lead a human life; being able to have good health; being able to move freely; being able to use the senses; being able to love; being able to contemplate; being able to engage in social interaction; being able to care for others; being able to laugh and to play; and being able to participate in collective decisions and hold property. Others suggested focusing and aggregating functionings (Clark 2005; Alkire 2007). The United Nations endorsed the Human Development Index (HDI) as the metric to measure the promotion of human development. This index is undergirded in Sen's work and the capability approach and expands the income metric by combining the former with life expectancy and literacy as the new metrics to assess human development. The HDI computes an average value over different dimensions and then aggregate 
these values for the different dimensions in one overall index for each country, and ranks the countries according to a score of the overall index.

\section{The Application of the Capability Approach}

The capability approach has been widely discussed and applied in the general literature (Schokkaert and van Ootegem 1990; Lovell et al. 1994; Oswald 1997; Anand et al 2005; Blanchflower and Oswald 2005; Leigh and Wolfers 2006; Moreno-Ternero and Roemer 2006). The human development debate in the wider academic world spurred interest in the role that tourism could play in the promotion of well-being and poverty reduction. The debate regarding the conceptualization and role of development in tourism studies closely resembles the debate in the mainstream literature (Scheyvens 2007). The debate has evolved from development equated with the income paradigm as a tool for modernization or as a tool for exploitation and domination, to development specifically focused as a yardstick for addressing poverty.

The revival of tourism as a development tool received its push from the pro-poor tourism literature (Brohman 1996; Clancy 1999; Ashley, Roe and Goodwin 2001; Sharpley and Teller 2002; Bah and Goodwin 2003; Meyer 2006; Hall 2007; Scheyvens 2007; Scheyvens and Momsen 2008; Mitchell and Ashley 2010). However, Goodwin (2007) suggests there is minimal documentation and data about the effects of tourism on poverty reduction. In order to understand the processes and ways how tourism can reduce poverty, robust methodologies need to be created. Harrison (2008) verifies this statement and suggests there has not been a clear link between poverty reduction and pro-poor projects. The connection between tourism development and development policies aimed at economic growth and poverty reduction is lacking in the scholarly tourism literature (Mitchell and Ashley, 2010). 
Traditionally, tourism development focuses on a limited economic impact analysis to enhance economic growth, instead of calculating impacts of poverty reduction. The poor typically would reap the benefits of growth through a plethora of benefits of tourism spending at the destination; this is known as a trickle-down effect (Modeste 1995; Durbarry 2004; Dritsakis 2004; Narayan 2004; Brau, Lanza, and Pigliaru 2007; Croes and Vanegas 2008; Sequeira and Nunes (2008). These studies are premised on the income paradigm and found a positive relation between tourism development and economic growth. Another focus in the tourism literature has been concerned with the subjective well-being of the individual, both as a traveler and as a host. For example, Cohen (2001), Neal, Sirgy and Uysal (2004), Perdue, Long and Kang (1999), Kim (2002), Gilbert and Abdullah (2002), Andereck, Valentine, Vogt and Knopf (2007), Cecil et al., (2008), Liburd and Derkzen (2009), Moscardo (2009), Benckendorff et al. (2009), Michalko, Kiss, Kovacs, and Sulyok (2009), and Andereck and Nyaupane (2011) focused on how tourism influences and impacts an individual's overall life satisfaction and found a positive relationship between the two variables. 


\section{Methodology}

One could infer based on the previous analysis that a person's achievements (functionings) are dependent on the resources that he commands and the ability to use these resources available. The relationship between achievements and resources can be construed as a production process where resources are considered inputs, while functionings or achievements will be considered as outputs. Inputs are defined as resources that matter in association with benefits realized in the process of economic growth. For example, the only commodity a majority of people possess is their labor power. Their ability to find a job and the wage the person is able to extract is crucial in determining the choices and opportunities one has in life. The lack of this ability impairs a person's well-being by removing the opportunity to earn income to buy food, to own property, to enjoy social reputation and to prevent discrimination.

On the other hand, enlargement of capabilities is an important contributor to the expansion of resources (e.g., incomes). However, this ability or capabilities (qualities of a person) to achieve functionings cannot be observed directly (Sen, 1999). It is assumed that capabilities are a mediating force in the conversion of resources into functionings. The study employs revealed achievements (literacy rate, life expectancy, incomes), following standard economics, to gauge a person's well-being. Functionings are, therefore captured through the concept of achievements and, following Sen's parsimonious premise, are measured by the human development index (HDI).

Basically, the HDI consists of three components: longevity, knowledge and standard of living. Longevity is measured by life expectancy. Knowledge is measured by a combination of adult literacy (two-third weight) and mean years of schooling (one-third weight). Finally, standard of living is measured by purchasing power based on Real GDP per capita adjusted for the cost of living (PPP) (UNDP, 1990). 
The study assumes that as tourist arrivals increase, so do total tourism receipts. For example, Sinclair and Stabler (1997) assert that an injection of tourist revenues into developing countries could have significant impact on their economies. Tourism has become an important economic activity for many developing countries in their quest to reduce poverty and increase prosperity (Clancy, 1999; Hawkins \& Mann, 2007; Croes \& Vanegas, 2008). However, the tourism development dynamics do not appear to be a simple relationship. Tourism expansion does not necessarily mean enhanced development gains for a destination. Leakages may mitigate against development. For example, employment for nationals may be limited in number and quality. The tourism development dynamics warrant therefore an empirical investigation.

The study asserts that tourism development has a positive relationship with human development based on the tourism-led growth (TLG) strategy, because increase incomes encapsulates a country's command over resources.

The functional form for this relationship is as follows:

$$
\mathrm{YHD}=f\left(\mathrm{XT}, \mu_{t}\right)
$$

Where YHD represents human development in period $(\mathrm{t})$; XT represents a vector of tourism spending, and $\mu_{t}$ represents the error term. Tourism expansion in this equation is captured by real tourism receipts at 2000 prices. Expressing equation (1) in logarithm form, in order to interpret elasticities, the study investigates the relationship,

(1) $\mathrm{LYHD}=\delta_{0}+\delta_{1} \mathrm{LXT}+\mu_{t}$

The study assumes that tourism growth (measured in the study as growth in real tourism receipts) generates a growth effects to the population of a destination and that growth effects will positively impact human development. A way to assess the effectiveness of the tourism effectiveness is the elasticity of human development with respect to real tourism receipts, as 
indicated in equation (2). It is further assumed that as people become healthier, better nourished and educated they become more productive in what they do thereby potentially having a positive impact on tourism spending. They may provide better services and more quality products. The study therefore investigates the inverse relationship of equation (2) as depicted in equation (3):

(2) $\mathrm{LXT}=\alpha_{0}+\alpha_{1} \mathrm{LYHD}+\theta_{t}$

The model is a log-linear one and the coefficient measures the proportionate change in human development associated with one year increase in tourism spending. The study will undertake four steps in running the regressions based on the models indicated previously: (1) the conduction of unit root tests applying the Augmented Dickey Fuller (ADF) and the PhillipsPerron (PP) tests; (2) the testing of cointegration based on the Granger representation theorem; (3) the application of the error correction analysis: and finally (4) the application of the Granger causality tests to determine mutually reinforcing interaction between the variables.

We assess the long run relationship among these variables by applying a cointegration analysis. The cointegration test is based on the Granger representation theorem, which basically posits that if two variables are cointegrated, their relationship has an error correction representation (Engle and Granger, 1987). Cointegration implies that the variables reviewed never drift apart from each other, i.e., they keep equilibrium in the long run. Surely, in the short term there may be disequilibrium among the variables. The error correction model captures both effects of the explanatory variables, i.e., one that occurs immediately and another impact dispersed across future time periods.

The cointegration relationship between non-stationary variables must be identified because the relationship implies a stable situation. In addition, whenever a cointegration relationship is established it means that there is no need to seek for the inclusion of other 
important variables (Song and Witt, 2000). The existence of cointegration encourages the application of the ECM specification.

If the two variables are indeed integrated, there is a long-term relationship that prevents them from migrating away from each other. For example, tourism spending effects human development and human development effects tourism spending. Thus, the two variables are expected to be equal. If the variables are indeed non-stationary, the result is favorable to conclude a false relationship. If, however, both variables are I(1), then their differences will be stationary. The conversion in growth may be retreated to the change of human development.

The cointegration analysis consists of two steps, i.e., the verification of the stationarity of the data (i.e., if the variables have constant mean and variance over time), and if they are stationary, then the study will employ the OLS technique. The first step involves applying a unit root test through the Augmented Dickey Fuller $(1979,1981)$ Test (ADF) and the Phillips Perron (1988) Test (PP). The advantage of the PP test over the ADF test is that the PP test is more robust to a wide variety of serial correlation and time dependent heteroskedasticity. These tests conclude if the two variables are stationary of order 0 , written as $\mathrm{I}(0)$, or if they follow a nonstationary trend of 1 denoted I(1) or higher. But before differencing thereby losing the long-run information in the data, it is important to test for cointegration.

To test for integration, each variable should be examined based on the following auxiliary equation:

(4) $\Delta y^{t}=\alpha+p y^{t-1}+\beta t+\sum \tau^{t} \Delta y^{t-1}+\mu^{t}$

Where $\left(\mathrm{y}^{\mathrm{t}}\right)$ is the relevant time series variable, $(\mathrm{t})$ is a linear deterministic trend and $\left(\mu^{\mathrm{t}}\right)$ is an error term with a mean of zero and a variance that is constant. If a cointegrating relationship is 
determined, then the study will proceed to run the cointegrating regression and to obtain the residuals. The following equations will be assessed:

$$
\begin{aligned}
& \mathrm{LYHD}_{t}=\beta_{0}+\beta_{1} \mathrm{LXT}_{t}+\mu_{t} \\
& \mu_{t}=\mathrm{LYHD}_{t}-\beta_{0}-\beta_{1} \mathrm{LXT}_{t}
\end{aligned}
$$

If a group I(1) variables is cointegrated then their combination should generate residuals that are $\mathrm{I}(0)$. Therefore the cointegrating test undertaken by this study takes the form of a unit root test applied to the residuals resulting from estimation of the cointegrating relationship. The second and final step involves, in case of acceptance of cointegration, the use of the lagged residuals stemming from the cointegration regression as an error correction term in an ECM. The ECM equation for the model under review is as follows:

$$
\begin{aligned}
& \Delta \mathrm{LYHD}_{t}=\alpha_{0}+\alpha_{1} \Delta \mathrm{LXT}_{t}+\alpha_{2} \mu_{t-1}+\varepsilon_{t} \\
& \Delta \mathrm{LXT}_{t}=\alpha_{0}+\alpha_{1} \Delta \mathrm{LYHD}_{t}+\alpha_{2} \mu_{t-1}+\varepsilon_{t}
\end{aligned}
$$

Where $\varepsilon^{t}$ is a white noise error term and $\mu^{t-1}$ is the lagged value of the error term.

This error correction specification implies that the change in one variable is related to the change in the other variables plus the gap between the variables in the previous period.

Therefore current changes in HD rely on current changes in LT as well as the extent to which the series are not in equilibrium in the previous period. $\alpha_{1}$ captures the short term effects of LT the previous period have on HD. $\alpha_{2}$ captures the rate at which HD adjusts to the equilibrium stage after a shock, i.e., the speed of error correction. 


\section{Estimated Results}

The data represent annual data for the period 1988-2005 and are from the World Development Indicators from the World Bank, the World Tourism Organization, and the Human Development Reports from 1990-2008 of the United Nations Development Program (UNDP). The data were converted in logs (gross domestic product and receipts) and in constant 2000 prices.

For the purpose of this study, a case study approach is employed to carry out research (i.e., model building). This study does not aim therefore at implementing or testing the efficacy of any model. The objective of a case study is to generalize theoretical propositions (analytic generalization) and does not contain a sample to make statistical generalization (Yin, 1994). A variant of the case study design is the comparative case method. Lijphart (1975) and George (1979) suggested that a comparative case study approach adds rigor to the scientific investigation process. The process should entertain two main characteristics: 1) they should entertain the same goals (e.g., the application of tourism as a development tool), but (2) manifest different characteristics in other aspects (dissimilar stage in tourism life cycle). For these reasons Costa Rica and Nicaragua have been selected as case studies.

These two Central America countries have used tourism as an economic and strategy to reduce poverty and to increase development. The countries have transformed their economies primarily based on traditional agriculture goods to an economy based on services and manufacturing. This transformation was required in order to remain competitive in a global marketplace. Costa Rica has a longer history of tourism development compared to Nicaragua (Hammill, 2007; Croes and Vanegas, 2008).

In addition, the two countries are extremes in terms of level of development. Whereas the level of extreme poverty in Nicaragua is around $45 \%$, in Costa Rica, the level of extreme poverty 
is less than $10 \%$. They also differ in terms of human development, level of incomes and high external debt. Costa Rica has a GDP per capita of US \$10,842 in 2009, while Nicaragua has a GDP per capita of only US\$2,570. Costa Rica's HDI in 2009 was 0.854 compared to Nicaragua's HDI of 0.699. Nicaragua is placed on The World Bank and IMF list of Highly Indebted Poor Countries (HICs), while Costa Rica is not.

To determine the presence of unit roots in the data sets, Augmented Dickey-Fuller (ADF) (1971, 1981) and Phillips-Perron (PP) (1988) tests were utilized. The ADF test used several regression equations (autoregressive process of order $\mathrm{P}$ ) to test for the presence of unit root. The difference between the equations concerns the presence of a deterministic element: drift and linear trend. To remove correlation in the residuals and to avoid a Type 1 error of rejecting the unit root tests' null hypothesis, two information criteria (AIC) and the (SBI) were implemented. The PP test suggests a non-parametric method for controlling for higher order of autocorrelation in a series which is based on a first order autoregressive (AR(1)) process. To account $t$ for the autocorrelation in the residuals, the non-parametric correction is made.

Tables 2 and 3 present the results of the ADR and PP tests of HD and LXT for Nicaragua and Costa Rica. STATA version 11 software package was used to conduct the ADT and PP tests to report the simulated critical values. The test statistics are compared with the critical value at the $5 \%$ level significance because human development and tourism receipts were found to have unit roots at this level. Unit root non-stationarity was rejected at the same level of significance, indicating I(1) processes.

\section{Insert Tables 2 and 3}


The study estimated the long run equation employing ordinary least squares (OLS) with variables, which are integrated in order I(1), in their levels suggested by Engle and Granger (1987). The conventional regression technique was used to estimate the residuals and to determine whether residuals were stationary or of in order I(0). Stationarity of residuals implies a cointegrating relationship among the variables in the long run equations. The results indicate that all the residuals, except equation 8 for Costa Rica, were stationary thereby confirming cointegration (see Table 4). The estimation results given in equation 8 for Costa Rica means that no cointegration relationship was found in the Costa Rica long-run model based on the EngleGranger procedure. Therefore, the ECM specification was not employed and the study did not interpret the meaning of the coefficients.

\section{Insert Table 4}

Following Engel and Granger (1987), the study proceeded to estimate the error correction model, based on the long run cointegrating relationship to detect the short run dynamics. The results are summarized in Tables 5 and 6. Tourism has a statistically significant long run and short run effect in the case of Nicaragua. The short term elasticity is about 0.01 (or 1\%), while the long term elasticity is 0.15 (or $1.5 \%$ ) and are both statistically significant at the 5 percent level. This means that increasing tourism receipts will lead to better HD performance. Better HD performance will also lead to increasing tourism receipts as revealed by Table 5, but the sort-run elasticity remains more or less the same as that in the long-run model.

Costa Rica displays a statistically significant long run relationship between tourism and HD. The estimated coefficient in the short-run ECM model is also significant at the 5\% level, but the latter turned out larger than the estimated long run coefficient, suggesting a situation of overshooting. This suggests that higher incomes stir spending in health and education almost 
immediately by households, but eventually this spending appears not sustainable and slacks over time. The results in the ECM further indicate that the coefficient of error term for the estimated tourism growth equation is negative as expected in both cases.

Statistically, the ECM term is significant for both Nicaragua and Costa Rica, suggesting that HD adjusts to tourism with a lag. Nearly 69 percent of the discrepancy between long term and short term HD is corrected within a year in the case of Nicaragua, while for Costa Rica the adjustment speed is close to 42 percent. This result implies that tourism expansion is enabling Nicaragua to converge to the HDI level of Costa Rica. This may be the case because Nicaragua is starting at a lower HDI level than Costa Rica.

The coefficient of the adjustment speed in the HD growth equation is also negative and statistically significant in the case of Nicaragua. This adjustment speed reveals a sluggish reaction, however, of only 7 percent annually. This result suggests that Nicaragua's low level of HDI, manifested by its low level of quality of labor and innovative capacity is hampering the destination to quickly come up with offerings that are appealing to tourists thereby commanding higher spending or demand. It is therefore no surprise that Nicaragua has been lagging in spending per arrival in the Central American Region.

\section{Insert Tables 5 and 6}

Finally, the study conducted the Granger causality test. The optimal lag length was established through the smallest values of Akaike (1974) (AIC) and Schwartz (1978) (SBC). Both criteria indicated lag 4 and 2 as the optimal lag for the annual data of Nicaragua and Costa Rica respectively. The results are displayed in Table 7. The case of Nicaragua indicates that Tourism and HD are mutually reinforcing because both hypotheses can be rejected at the $1 \%$ significance level. This means that in the case of Nicaragua that the effects of tourism expansion 
on households' income and government expenditures on human development complement each other. On the other hand, an increase in education and health may have triggered more skill acquisition and nutritional intake thereby boosting productivity.

The case of Costa Rica only suggests a one-directional relationship between Tourism and HD, rejecting the hypothesis that tourism does not Granger cause HD. It appears that after making significant strides in poverty reduction in the country, Costa Rica has not been able to convert improved education and health indicators into productivity gains. According to Gindling (2009) inequality levels in Costa Rica have increased since the decade of the nineties and poverty rates have stagnated despite economic growth.

\section{Insert Table 7}




\section{Conclusion}

Sen's capability approach has broadened the definition and goals of development. Sen's perspective combines attributes (e.g., incomes) with an enlargement of opportunities available to a person. How the two are linked together is the probe of this study. Consequently, the study sought to answer three interrelated questions: (i) is there a relationship between tourism expansion and human development; (ii) if there is a relationship, what is the nature of that relationship; and (iii) what is the direction of the relationship. The empirical investigation focused on two developing countries located in Central America, i.e., Nicaragua and Costa Rica. The selection of these two countries was undergirded in the comparative approach as suggested by Lijphart (1975) and George (1979).

The results reveal the connectivity between tourism and human development in the case of Nicaragua. Tourism growth expands capabilities directly suggesting that as average tourism receipts increase, the population seems to have greater command over relevant resources (education, health, food, etc.) which lead to better human development performance. This connectivity is furthermore mutually reinforcing: as human development performance improves, tourism services improve thereby yielding higher tourism revenues. Tourism revenues in Nicaragua have significantly increased over time, confirming this finding (Croes and Vanegas, 2008). Actually, revenues have increased more than 24 times, from $\$ 12$ million to $\$ 309$ million between 1990 and 2010. The policy implication is that tourism growth accompanied with HD improvements appears to yield a stable relationship over time.

While tourism revenues have increased, the yield per arrival has decreased over time. While spending per arrival increased by 61 percent between 1990 and 2004, that ratio was merely 5 percent from 2005 to 2010 . The spending per arrival in Nicaragua in 2010 only 
represents 35 percent of the average spending per arrival in Central America. The low productivity in terms of spending per arrival compounded by its dramatic slow-down over time indicates that Nicaragua has not been able to provide the tourists with higher value offerings. This finding could be attributed to the low quality of skills available in Nicaragua which is hampering product development and innovation. Croes and Tesone (2004) found in 2004 that less than $1 \%$ of the employees in the tourism sector in Nicaragua used computers in their work compared to $29 \%$ in Costa Rica. This may well be the explanation of the sluggish adjustment of tourism to HD improvements.

The tenuous dual link between tourism development and HD in Nicaragua merits some further thoughts. It seems evident that tourism development will enhance HD in Nicaragua. Higher tourism revenues correlate with improvements in health and education, as higher household incomes and government expenditures focusing on health and education programs have addressed pressing social and human issues in the country. For example, since the last decade the Government of Nicaragua has been providing free and universal access in health and education. Maternal and child health has seen significant improvements over the years, while, according to UNESCO the illiteracy rate was reduced from 22 percent to less than 6 percent. The Red de Proteccion Social (RPS) bolstered these programs thereby promoting HD improvements (Malucio and Flores, 2005).

These improvements, no matter how significant, are the solution to less complex social issues in human development. For example, gains in life expectancy through the eradication of preventable diseases are much easier than halting complex diseases, such as cancer. Similarly, lower levels of education are easier to improve (primary education) compared to the diffusion of higher education and higher skills. Providing access to health and schools as a first step is 
important to improve the quality of life of people, but after reaching a certain threshold of accessibility, the quality of services becomes crucial in further improving the quality of life of the people. The payoff of tourism development may be indicating threshold effects dependent on the fraction of the labor market that has skills. Beyond a threshold other factors may come to play, such as institutional strength, the distribution of income, social expenditure ratios, and the relative position of women.

The Costa Rica case seems to corroborate the tenuousness of the dual link between tourism development and HD improvements. Evidentiary factors, such as the larger short run coefficient compared to that of the long run, and the lack of long run relationship running from HD to tourism development, point to an unstable relationship over time. While higher tourism incomes lead to HD improvements, over time these effects tend to diminish. This situation may reflect uncertainty confronted by those earning an income in the tourism sector. This uncertainty may be caused by the job types and characteristics (part time and predominance of women) in tourism in Costa Rica (Ferguson, 2010), by a crime environment which has an increasingly effect on health costs (Acevedo, 2008), and by lowering productivity which eventually would lower incomes thereby negatively affecting human development efforts by households (Alaimo et al, 2009). Part time and low-pay female workers tend to spend their income quickly and mainly on food and health items (Ferguson, 2010).

The distribution of tourism revenues has a strong impact on HD, particularly in poor households. The reason is that these households spend a larger proportion of their income on food, health and education. According to Gindling (2009) inequality levels in Costa Rica have increased since the decade of the nineties and poverty rates have stagnated despite economic growth. Poverty levels have stagnated around the $30 \%$ of the population and this group has also 
been the target of increased crime. Crime is taxing vulnerable population segments the most resulting in increasing health and other costs (Acevedo, 2008). Tourism development in the case of Costa Rica appears unable to further HD improvements.

This evidence does not imply however that tourism growth is unimportant to broadening human development; rather it is suggesting that the importance of tourism growth is merited in the distribution of its benefits, and the extent that tourism receipts are allocated to support human development (public health, education, safety, etc.). The larger implication from the evidence of this study is that rising incomes will not necessarily translate into human development performance, thereby rendering support to Sen's contention that well-being should not be measured by its instrumental antecedents (such as income) alone. Private incomes through tourism expansion seem to matter most at lower level of human development as indicated by the case of Nicaragua. Beyond some point of human development performance tourism will entertain only a weak link with capabilities, suggesting that a policy of human development with less emphasis on private incomes is implied.

Surely, the conclusions and implications warrant some qualifications. The results may not generalize to other countries and to a larger pool of indicators of human development as captured by the HDI. For example, food may be more responsive to tourism revenues than education or health. Employing the HDI as a proxy for human development and treating human development, therefore, as an aggregate in the regressions is unsatisfactory. How the increased tourism revenues are being allocated by the different groups in each country matters to the impact of social outcomes.

Future research will not only expand the number of countries to be reviewed to test the relationship between tourism development and human development (more cross country 
evidence), but also will investigate the relationship over time for the same country, as well as the sequencing of the link tourism development and HD. In addition, it seems relevant to understand the factors that matter to this relationship, in other words, to investigate important contributory factors that nurture the link between tourism development and human development. 


\section{REFERENCES}

Aghion, Phillipe and Patrick Bolton (1997). “A Theory of Trickle-down Growth and Development." The Review of Economic Studies, 64(2): 151-172.

Alaimo, Verónica, Pablo Fajnzylber, J. Luis Guasch, J. Humberto López, and Ana María Oviedo. 2009. "Behind the Investment Climate: Back to Basics—Determinants of Corruption.” In Does the Investment Climate Matter? Microeconomic Foundations of Growth in Latin America, ed. Pablo Fajnzylber, J. Luis Guasch, and J. Humberto López, 139-78. Washington, DC: World Bank.

Alkire, Sabina (2007). “The Missing Dimensions of Poverty Data: Introduction to the Special Issue." Oxford Development Studies, 35(4): 347-359.

Anand, Sudhir, and Martin Ravallion (1993). "Human Development in Poor Countries: On the Role of Private Incomes and Public Services.” Journal of Economic Perspectives, 7(1): 133-150.

Anand, Paul, Graham Hunter, and Rob Smith (2005). "Capabilities and Well-Being: Evidence Based on Sen-Nussbaum Approach to Welfare." Social Indicators Research, 74: 9-55.

Andereck, Kathleen and Nyaupane, Gyan (2011). "Exploring the Nature of Tourism and Quality of Life Perceptions among Residents." Journal of Travel Research, 50(3):248-260.

Andereck, Kathleen, Karin M. Valentine, Christine A. Vogt, and Richard C. Knopf (2007). "A Cross-Cultural Analysis of Tourism and Quality of Life Perceptions." Journal of Sustainable Tourism, 15(5): 483-502.

Ashley,C., Roe, D. and Goodwin, H., “.(2001). Pro-Poor Tourism Strategies: Making Tourism Work for the Poor: A Review of Experience," Pro-Poor Tourism Report 1, ICRT, IIED and ODI (London, 2001). 
Bah, A. and Goodwin, H., "Improving Access to the Informal Sector to Tourism in Gambia," Pro-Poor Tourism Working Paper 15, ICRT, IIED, ODI, (London, 2033).

Balaguer, Jacint, and Manuel Cantavella-Jorda (2002). "Tourism as a Long-Run Economic

Growth Factor: The Spanish Case.” Applied Economics, 34(1): 877-884.

Banerjee, Abhijit V. and Esther Dufloha (2007). "The Economic Lives of the Poor.” Journal of Economic Perspectives, 21(1): 141-167.

Benckendorff, Pierre, Deborah Edwards, Claudia Jurowski, Janne J. Liburd, and Gianna Moscardo (2009). "Exploring the Future of Tourism and Quality of Life." Tourism and Hospitality Research, 9(2): 171-183.

Blake, Adam, Jorge S. Arbache, M. Thea Sinclair, and Vladimir Teles (2008). "Tourism and Poverty Relief.” Annals of Tourism Research, 35(1): 106-127.

Blanchflower, David G., and Andrew J. Oswald (2005). "Well-Being Over Time in Britain and the USA.” Journal of Public Economics, 88: 1359-1386.

Brau, Rinaldo, Alessandro Lanza, and Francesco Pigliaru (2007). "How Fast are Small Tourism Countries Growing? Evidence From the Data 1980-2003.” Tourism Economics, 13(4): 603-613.

Brohman, J. (1996). "New Directions in Tourism for Third World Development.” Annals of Tourism Research, 23: 48-70.

Cecil, Amanda K., Fu Yao-Yi, Wang Suosheng, and Sotiris H. Avgoustis (2008). "Exploring Resident Awareness of Cultural Tourism and its Impact on Quality of Life.” European Journal of Tourism Research, 1(1): 39-52.

Clancy, Michael J. (1999). “Tourism and Development: Evidence From Mexico.” Annals of Tourism Research, 26: 1-20. 
Clark, David A. (2005). "Sen's Capability Approach and the Many Spaces of Human WellBeing.” The Journal of Development Studies, 41(8): 1339-1368.

Cohen, Jeffrey H. (2001). “Textiles, Tourism and Community Development.” Annals of Tourism Research, 28(2): 378-398.

Cracolici, Maria F., and Peter Nijkamp (2009). "The Attractiveness and Competitiveness of Tourist Destinations: A Study of Southern Italian Regions.” Tourism Management, 30: 336-344.

Croes, Robertico and Dana Tesone (2004). "Small Firms Embracing Technology and Tourism Development: Evidence from Two Nations in Central America." International Journal of Hospitality Management, 23(1): 557-564.

Croes, Robertico and Manuel Vanegas Sr. (2008). “Tourism and Poverty Alleviation: A CoIntegration Analysis." Journal of Travel Research, 47(1): 94-103.

Dickey, David A. and Wayne A. Fuller (1979). "Distribution of the Estimators for Autoreggresive: Time Series with a Unit Root.” Journal of the American Statistical Association, 74: 427-31.

Dickey, David A., and Wayne A. Fuller (1981). "Likelihood Ratio Statistics for Autoregression: Time Series with a Unit Root.” Econometrica, 49: 1057-1072.

Dollar, D and Kraay, A. (2002). "Growth is Good for the Poor." Journal of Economic Growth, 7, 195-225.

Dritsakis, Nikolaos (2004). “Tourism as a Long-Run Economic Growth Factor: An Empirical Investigation for Greece Using Causality Analysis.” Tourism Economics, 10(3): 305316.

Durbarry, Ramesh (2004). "Tourism and Economic Growth: The Case of Mauritius.” Tourism Economics, 10(4): 389-401. 
Easterly, Williams (2002). The Elusive Qwest for Growth. Cambridge, MA: MIT Press.

Engle, Robert F., and C.W.J. Granger (1987). “Co-Integration and Error Correction: Representation, Estimation, and Testing.” Econometrica, 55: 251-76.

George, A. (1979). Case Studies and Theory Development: the Method of Structured, Focused Comparison. In Lauren, P.G. (Ed.). Diplomacy: New Approaches in History, Theory and Policy (43-68). New York: Free Press.

Gilbert, David and Junaida Abdullah (2002). "A Study of the Impact of the Expectation of a Holiday on an Individual's Sense of Well-Being." Journal of Vacation Marketing, 8(4): $352-361$.

Gindling, T. (2009). South-South Migration: The Impact of Nicaraguan Immigrants on Earnings, Ineqaulity and Poverty in Costa Rica. World Development 37 (1), 116-126.

Goodwin, H. (2007). Measuring and Reporting the Impact of Tourism on Poverty. In Airey, D. and Tribe, J. (eds.). Developments in Tourism Research: New directions, challenges and applications (Advances in Tourism Research. Oxford: Elsevier.

Hall, C. (2007). Pro-Poor Tourism” Do ‘Tourism Exchanges Benefit Primarily the Countries of the South'?. Current Issues in Tourism, 10(2\&3), 111-118.

Hammill, Matthew (2007). Growth, Poverty and Inequality in Central America. Mexico D.F.: CEPAL.

Harrison, D. (2008). Pro-poor Tourism: a critique. Third World Quarterly 29 (5) 851-868. Hashimoto, A. (2002). “Tourism and Sociocultural Development Issues." In Tourism and Development. Concepts and Issues, edited by Richard Sharpley and David J. Telfer. Clevedon, United Kingdom: Channel View Publications. 
Hawkins, Donald E., and Shaunn Mann (2007). “The World Bank's Role in Tourism

Development." Annals of Tourism Research, 34(2): 348-363.

Kakwani, N. (2000). Economic Growth, Poverty and Income Support Programs in Australia. Journal of Asia Pacific Economy 5(1\& 2), 14-37.

Kakwami,N. and Pernia, E. (2000). What is Pro-Poor Growth? Asian Development Review $18(1), 1-16$.

Kim, Kyungmi. (2002). “The Effects of Tourism Impacts Upon Quality of Life of Residents in the Community." (Ph.D. dissertation unpublished).

Leigh, Andrew and Justin Wolfers (2006). "Happiness and the Human Development Index: Australia is Not a Paradox." The Australian Economic Review, 39(2): 176-84.

Liburd, Jane J., and Petra Derkzen (2009). "Emic Perspectives on Quality of Life: The Case of the Danish Wadden Sea Festival.” Tourism and Hospitality Research, 9(2): 132-146.

Lijphart, A (1975). The Comparable-cases Strategy in Comparative Research. Comparative Political Studies, 8, 158-177.

Lopez, H. and Serven, L. (2004). The mechanics of growth-poverty-inequality relationship, Mimeo, The World Bank.

Lovell, C., Richardson, S., Travers, P., \& Wood, L. (1994). "Resources and Functionings: A New View of Inequality in Australia." In Models and Measurement of Welfare and Inequality, edited by Wolfgang Eichhorn. Heidelberg, Germany: Springer-Verlag.

Maluccio, J., and Flores, R. (2005). "Impact Evaluation of the Pilot Phase of the Nicaraguan Red de Protección Social.” Research Report 141. Washington: International Food Policy Research Institute. 
Mbaiwa, Joseph E. (2005). “The Problems and Prospects of Sustainable Tourism Development in the Okavango Delta, Botswana." Journal of Sustainable Tourism, 13(3): 203-227.

Michalko, Gabor, Kornelia Kiss, Balazs Kovacs, and Judit Sulyok (2009). “The Impact of Tourism on Subjective Quality of Life Among Hungarian Population.” Hungarian Geographical Bulletin, 58(2): 121-136.

Mitchell, Jonathan and Ashley, C. (2010). Tourism and Poverty Reduction: Pathways to prosperity. London: Overseas Development Institute, Earthscan.

Meyer, D. (2006). Caribbean Tourism, local sourcing, and enterprise development: review of the literature. PPT Working paper 18.

Modeste, N. (1995). The impact of growth in the tourism sector on economic development: the experience of selected Caribbean countries. Economia Internazionale 48, 375-385.

Moreno-Ternero, Juan D. and John E. Roemer (2006). "Impartiality, Priority, and Solidarity in the Theory of Justice." Econometrica, 74(5): 1419-1427.

Morse, Stephen (2003). "Greening the United Nations' Human Development Index." Sustainable Development, 11: 183-198.

Moscardo, Gianna (2009). “Tourism and Quality of Life: Towards a More Critical Approach.” Tourism and Hospitality Research, 9(2): 159-170.

Narayan, Paresh Kumar (2004). “Tourism Demand Modeling: Some Issues Regarding Unit Roots, Cointegration and Diagnostic Tests." International Journal of Tourism Research, 5: 369-380.

Neal, J., Sirgy, J., and Uysal, M. (2004). Measuring the effect of tourism services on travelers' quality of life; further validation. Journal of Social Indicators 69(3), 243-249. 
Nussbaum, Martha C. (2000). Women and Human Development: A Study in Human

Capabilities. Cambridge: Cambridge University Press.

Nussbaum, Martha C. (2006). "Poverty and Human Functioning: Capabilities as Fundamental Entitlements." In Poverty and Inequality edited by David B. Grusky and Ravi Kanbur. Stanford: University Press.

Oswald, Andrew J. (1997). "Happiness and Economic Performance.” The Economic Journal, 107: $1815-1831$.

Purdue, Perdue R., Patrick T. Long, and Yong Soon Kang (1999). “Boomtown Tourism and Quality of Life: The Marketing of Gaming to Host Community Residents.” Journal of Business Research, 44(3): 165-177.

Phillips, Peter C. B. Phillips and Pierre Perron (1988). "Testing For a Unit Root in Time Series Regression” Biometrika, 75(2): 335-346.

Ranis, Gustav and Frances Stewart (2000). "Economic Growth and Human Development." World Development, 28(2): 197-219.

Ranis, G. and Ramirez, A. (2000). Economic growth and human development. World Development 28(2), 197-219.

Ranis, Gustav, Frances Stewart, and Emma Samman (2006). "Human Development: Beyond the Human Development Index.” Journal of Human Development, 7: 323-358.

Ravallion, M. and Chen, S. (2003). Measuring Pro-Poor Growth. Economics Letters 78(1), 9399.

Ravallion, M. (2004). Pro-Poor Growth: a Primer. World Bank Policy Research Paper No.3242, Washington DC: World Bank. 
Robeyns, Ingrid (2005). “The Capability Approach: A Theoretical Survey.” Journal of Human Development, 6(1): 93-114.

Sanders, Todd. (2001). Economic Concepts for the Social Sciences. New York: Cambridge University Press.

Scheyvens, R. (2007). Exploring the Tourism-Poverty Nexus. Current Issues in Tourism $10(2 \& 3), 231-254$

Scheyvens, R and J. Momsen (2008) Tourism and Poverty Reduction: Issues for Small Island States. Tourism Geographies, 10(1): 22-41.

Schokkaert, Erik and Luc Van Ootegem (1990). “Sen’s Concept of the Living Standard Applied to the Belgian Unemployed." Recherches Economiques de Louvain, 56(3-4): 429-450.

Sen, Amartya (1982). Poverty and Famines: An Essay on Entitlements and Deprivation. Oxford: Clarendon Press.

Sen, Amartya (1985). Commodities and Capabilities. New York: Elsevier Science.

Sen, Amartya (1990). "Development as Capability Expansion." In Human Development and the International Development Strategy for the 1990s, edited by Keith Griffin and John Knight. London: McMillan. Pp 41-58.

Sen, Amartya (1992). Inequality reexamined. Oxford: Clarendon Press

Sen, Amartya (1997). On Economic Inequality. Oxford: Clarendon Press

Sen, Amartya (1999). Development as Freedom. New York: Anchor Books.

Sen, Amartya (2000). A Decade of Human Development. Journal of Human Development 1(1): $17-23$.

Sequeira, Tiago Neves and Paulo Nunes (2008). "Does Tourism Influence Economic Growth? A Dynamic Panel Data Approach.” Applied Economics, 40(18): 2431-2441. 
Shah, K. and Gupta, V. (eds.) (2000). Tourism, the Poor and Other Stakeholders: Experience in Asia. Overseas Development Institute and Tourism Concern, London.

Sharpley, R. and Telfer, D.(eds.) (2002). Tourism and Development: Concepts and Issues.

Clevedon, UK: Channel View Publications. Sinclair, M. Thea and M. J. Stabler. (1997). The Economics of Tourism. London: Routledge.

Solow, R. (1956). A contribution to the theory of economic growth. Quarterly Journal of Economics 70 (1): 65-94

Song, H and Witt, S. (2000). Tourism Demand Modelling and Forecasting. Modern Economic Approaches. Oxford, UK: Pergamon.

Torres, R. and Momsen, J.H. (2004). Challenges and potential for linking tourism and agriculture to achieve pro-poor tourism objectives. Progress in Development Studies, 4(4), 294-318.

United Nations Development Program (UNDP) (1990). Human Development Report 1990. New York: NY, Oxford University Press.

United Nations Development Program (UNDP) (2010). Report on Human Development in Central America 2009-2010. New York, NY: Oxford University Press.

White, H. and Anderson, A. (2000). Growth vs. Redistribution: Does the Pattern of Growth Matter?. DFID white paper on Eliminating World Poverty: Making Globalisation Work for the Poor.

Yin, R. (1994). Case Study Research, Design and Methods. Thousand Oaks, CA: Sage Publications. 
Figure 1: The Capability Approach

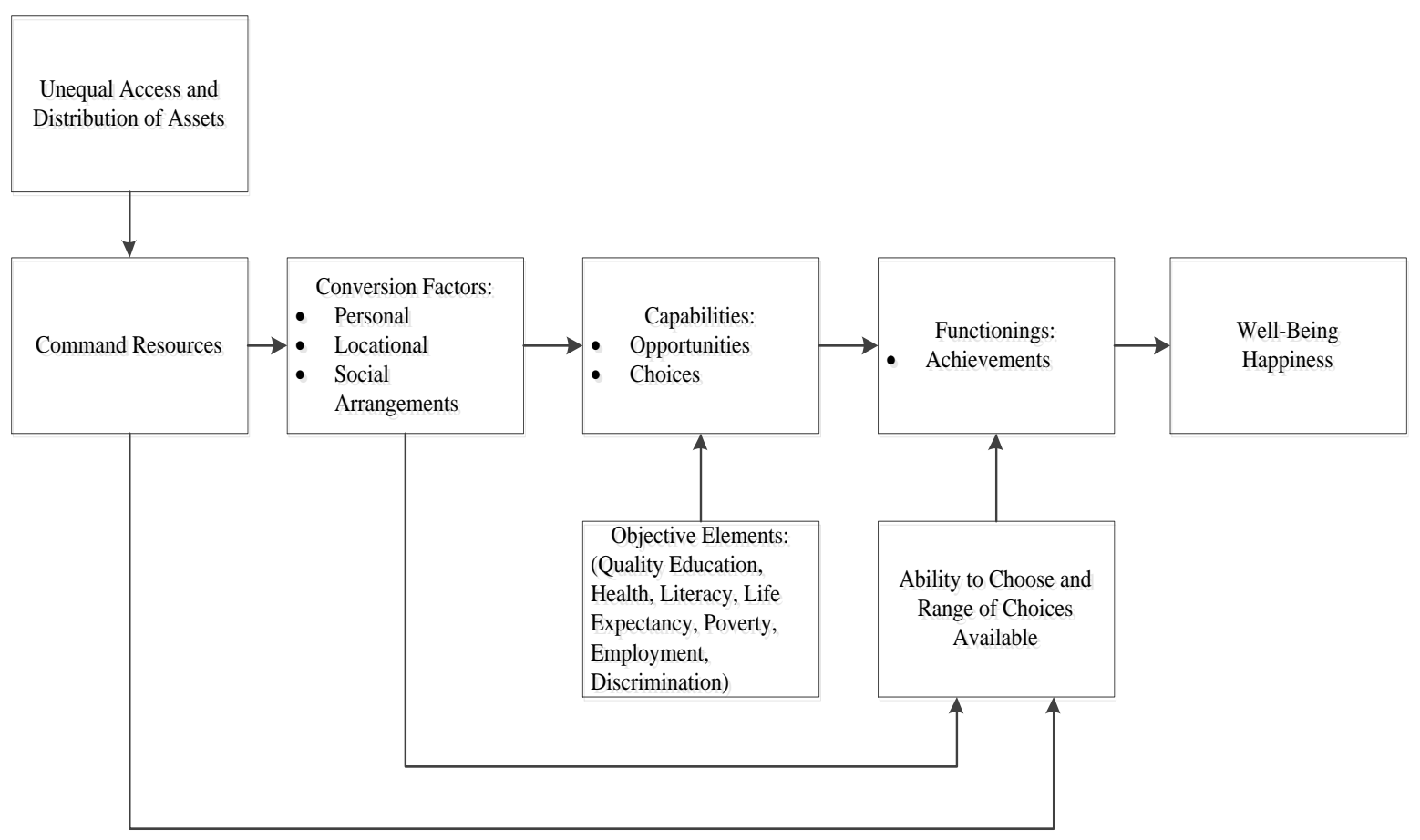


Table 1: Selected Countries in Latin America and the Caribbean 2009

\begin{tabular}{lcc}
\hline \multicolumn{1}{c}{ Country } & HDI & $\begin{array}{c}\text { GDP/capita } \\
\text { (PPPUS } \mathbf{\text { ) }}\end{array}$ \\
\hline Mexico & 0.841 & 14,104 \\
Honduras & 0.732 & 3,796 \\
El Salvador & 0.747 & 5,804 \\
Guatemala & 0.704 & 4,562 \\
Costa Rica & 0.854 & 10,842 \\
Nicaragua & 0.699 & 2,570 \\
Panama & 0.840 & 11,391 \\
Colombia & 0.807 & 8,587 \\
Venezuela & 0.844 & 12,156 \\
Ecuador & 0.806 & 7,449 \\
Peru & 0.806 & 7,386 \\
Brazil & 0.813 & 9,567 \\
Paraguay & 0.761 & 4,433 \\
Bolivia & 0.729 & 4,206 \\
Argentina & 0.866 & 13,238 \\
Chile & 0.878 & 13,880 \\
Barbados & 0.903 & 17,956 \\
Uruguay & 0.865 & 11,216 \\
Cuba & 0.863 & 6,876 \\
Bahamas & 0.856 & 20,253 \\
Trinidad \& Tobago & 0.837 & 23,507 \\
Dominican Republic & 0.777 & 6,706 \\
Jamaica & 0.766 & 6,079 \\
Haiti & 0.532 & 1,155 \\
\hline & &
\end{tabular}


Table 2. Augmented Dickey Fuller (ADF) Unit Root Test Results

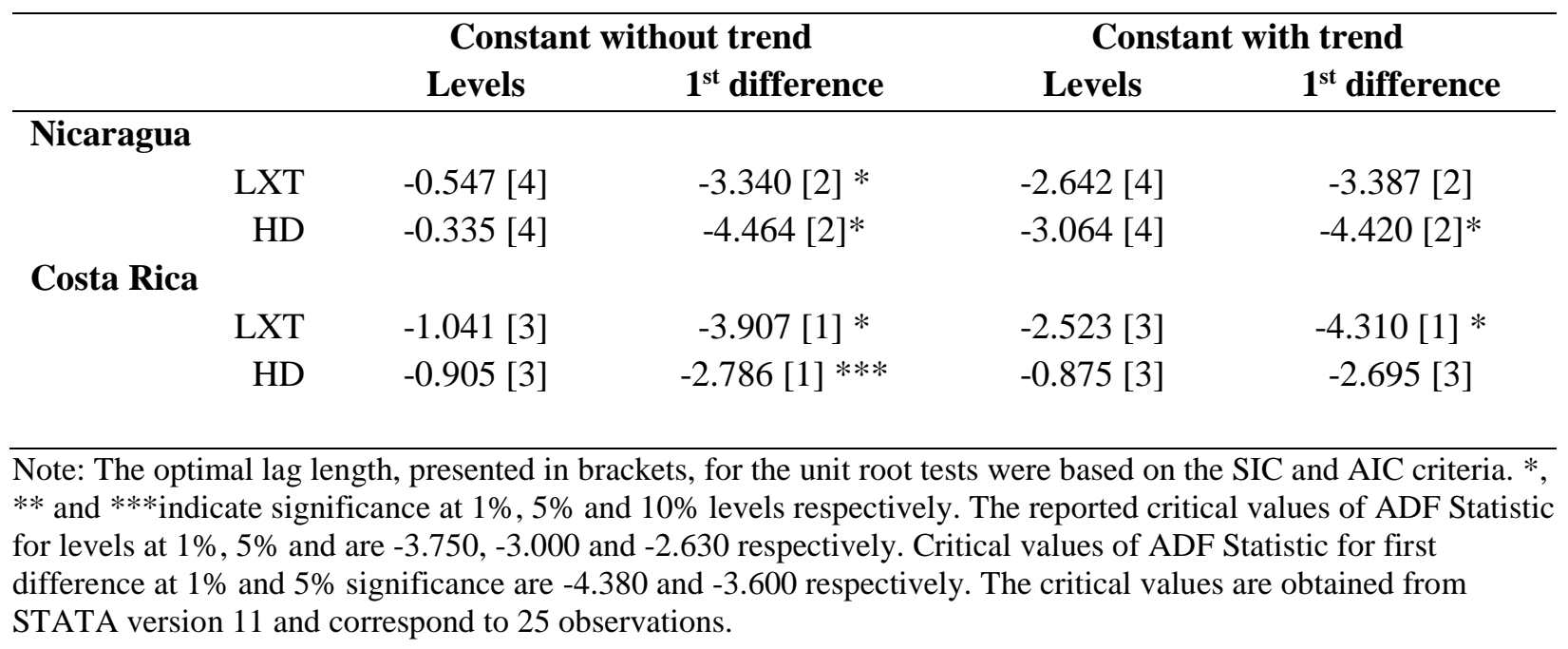


Table 3. Phillips Perron Test (PP) Unit Root Test Results

\begin{tabular}{|c|c|c|c|c|}
\hline & \multicolumn{2}{|c|}{ Constant without trend } & \multicolumn{2}{|c|}{ Constant with trend } \\
\hline & Levels & $1^{\text {st }}$ difference & Levels & $1^{\text {st }}$ difference \\
\hline \multicolumn{5}{|l|}{ Nicaragua } \\
\hline LXT & $-5.569[4] *$ & $-7.052[2] *$ & $-3.695[3] * *$ & $-19.966[2] *$ \\
\hline HD & $-2.348[4]$ & $-3.838[2] *$ & $-0.983[3]$ & $-3.449[2] *$ \\
\hline \multicolumn{5}{|l|}{ Costa Rica } \\
\hline LXT & $-1.111[3]$ & $-3.902[1] *$ & $-2.239[3]$ & $-3.780[3] *$ \\
\hline HD & $-0.549[3]$ & $-4.267[2] *$ & $-2.490[3]$ & $-4.036[2] *$ \\
\hline
\end{tabular}


Table 4 Residual based Stationarity Test

\begin{tabular}{|c|c|c|c|c|c|c|}
\hline Country & $\begin{array}{c}\text { Variable } \\
\text { from } \\
\text { Equation }\end{array}$ & $\begin{array}{c}\text { Order of } \\
\text { integration }\end{array}$ & $\begin{array}{c}\text { Test } \\
\text { Equation } \\
\text { Type }\end{array}$ & $\begin{array}{c}\text { ADF Test } \\
\text { Statistic }\end{array}$ & $\begin{array}{c}\text { MacKinnon } \\
\text { critical } \\
\text { values }\end{array}$ & Conclusions \\
\hline Nicaragua & $\begin{array}{c}\text { Residual } \\
\text { term LXT- } \\
\text { HD }\end{array}$ & Level & $\begin{array}{c}\text { Constant } \\
\text { Constant } \\
\text { with trend }\end{array}$ & $\begin{array}{l}-3.448[1] \\
-5.520[1]\end{array}$ & $\begin{array}{c}0.009 \\
0.0000\end{array}$ & $\mathrm{I}(0)$ \\
\hline \multirow{3}{*}{ Costa Rica } & $\begin{array}{c}\text { Residual } \\
\text { term HD- } \\
\text { LXT }\end{array}$ & Level & $\begin{array}{l}\text { Constant } \\
\text { Constant } \\
\text { with trend }\end{array}$ & $\begin{array}{l}-3.276[1] \\
-4.669[1]\end{array}$ & $\begin{array}{l}0.0521 \\
0.0008\end{array}$ & $\mathrm{I}(0)$ \\
\hline & $\begin{array}{c}\text { Residual } \\
\text { term LXT- } \\
\text { HD }\end{array}$ & Level & $\begin{array}{c}\text { Constant } \\
\text { Constant } \\
\text { with trend }\end{array}$ & $\begin{array}{l}-4.071[1] \\
-3.6214[1]\end{array}$ & $\begin{array}{l}0.0001 \\
0.0287\end{array}$ & $\mathrm{I}(0)$ \\
\hline & $\begin{array}{c}\text { Residual } \\
\text { term HD- } \\
\text { LXT }\end{array}$ & Level & $\begin{array}{c}\text { Constant } \\
\text { Constant } \\
\text { with trend }\end{array}$ & $\begin{array}{l}-1.082[2] \\
-2.845[1]\end{array}$ & $\begin{array}{l}0.5985 \\
0.1803\end{array}$ & $\begin{array}{c}\text { Not } \\
\text { stationary }\end{array}$ \\
\hline
\end{tabular}

Source: Author's calculations based on STATA11 
Table 5. Estimating Nicaragua's long-term and short-term coefficients of Tourism and Human Development.

\begin{tabular}{ccccccc}
\hline Equation & $\begin{array}{c}\text { Cointegrating } \\
\text { Coefficients }\end{array}$ & $\begin{array}{c}\text { Short } \\
\text { Term } \\
\text { Coefficient }\end{array}$ & $\begin{array}{c}\text { EC* } \\
\text { coefficient }\end{array}$ & $\mathbf{R}^{2}$ & $\begin{array}{c}\text { p- } \\
\text { value }\end{array}$ & DW $^{* *}$ \\
\hline 7 & $0.154^{*}$ & $0.095^{*}$ & $-0.687^{*}$ & 0.5187 & 0.0029 & 1.89 \\
& $(4.24)$ & $(3.07)$ & $(-3.61)$ & & & \\
& & & & & & \\
8 & $1.04^{*}$ & $1.03^{*}$ & $-0.070^{*}$ & 0.3331 & 0.0479 & 2.51 \\
& $(3.96)$ & $(2.69)$ & $(-2.44)$ & & & \\
\hline
\end{tabular}

Note: * EC=Error Correction; ** DW=Durbin Watson. t-statistics are in parentheses and * indicates 5\% significance level. 
Table 6. Estimating Costa Rica's long-term and short-term coefficients of Tourism and Human Development.

\begin{tabular}{ccccccc}
\hline Equation & $\begin{array}{c}\text { Cointegrating } \\
\text { Coefficients }\end{array}$ & $\begin{array}{c}\text { Short } \\
\text { Term } \\
\text { Coefficient }\end{array}$ & $\begin{array}{c}\text { EC* } \\
\text { coefficient }\end{array}$ & $\mathbf{R}^{2}$ & $\begin{array}{c}\text { p- } \\
\text { value }\end{array}$ & DW $^{* *}$ \\
\hline 7 & $0.114^{*}$ & $0.198^{*}$ & $-1.03^{*}$ & 0.6062 & 0.0024 & 1.73 \\
$(-4.57)$ & $(3.35)$ & $(-3.31)$ & & & \\
8 & 1.77 & -- & -- & -- & -- & -- \\
\hline
\end{tabular}

Note: *EC=Error Correction; ** DW=Durbin Watson. t-statistics are in parentheses; * indicates $5 \%$ significance level. 
Table 7. Pair wise Granger Causality Estimation

\begin{tabular}{rcccc}
\hline & \multicolumn{2}{c}{ Nicaragua } & \multicolumn{2}{c}{ Costa Rica } \\
Null hypothesis & F-Statistic & Probability & F-Statistic & Probability \\
\hline LXT does not cause HD & 39.069 & 0.000 & 6.032 & 0.049 \\
HD does not cause LXT & 18.652 & 0.001 & 0.768 & 0.722 \\
& & & & \\
\hline
\end{tabular}

Note: The maximum lag length applied to Nicaragua and Costa Rica was 4 and 2 respectively. 